\title{
Media Massa dalam Masyarakat Madani
}

\author{
Rita Gani
}

ABSTRACT

The life of Prophet Muhammad inherited us with great values that become exemplar for society after him. Madinah Charter in the time of the Great Prophet was introduced as written rules to manage people life - through this Charter, pecially civil defense. Such norms are still relevant enough being applied in modern times. Freedom of the press in civil society translated not as absolute freedom. Censorship is still recognized in the form of norms, ethics, culture, religion, and custom-traditions among members of community. In effect, mass media in civil society aren't free from social realities.

Kata kunci: masyarakat madani, media massa, realitas sosial

\section{Latar Belakang Masalah}

"The mass media become the authority at any given moment for what is false, what is reality and what is fantasy, what is important and what is trivial" (Ben H. Bagdikian dalam Subandy, 2000:1). Media massa, baik surat kabar, radio, televisi, maupun film, telah menjadi sahabat bagi kehidupan masyarakat di era globalisasi ini. Hal ini begitu terasa sejak tumbangnya Presiden Soeharto pada Mei 1998. Kebebasan yang dituntut banyak pihak atas "kekangan" selama Orde Baru berimbas pada tuntutan kebebasan pers, meskipun tetap berpedoman kepada pers Pancasila atau pers yang bebas bertanggung jawab.

Era reformasi dalam kehidupan pers Indonesia diawali dengan melonggarnya birokrasi dalam sistim penerbitan pers. Misalnya, dengan dihapuskannya Surat Izin Usaha Penerbitan Pers (SIUPP) yang ditetapkan oleh Permenpen No. 01/ Per/Menpen/1984 tentang SIUPP, 5 Juni 1984, yang selama ini seolah menjadi "tembok tebal" yang menghalangi kreativitas insan pers untuk menerbitkan satu bentuk media massa (terutama media massa cetak).

Kewajiban media massa nantinya hanya berbadan hukum, penanggung jawab dan alamatnya jelas, serta percetakannya di cantumkan. Selama hampir satu dekade era reformasi dilalui, media massa di tanah air tumbuh bak jamur di musim hujan. Pers di harapkan akan lebih otonom dan independen dalam menjalankan fungsinya. Ia menjadi salah satu pilar demokrasi, dengan tugas utamanya mengoptimalkan fungsi kontrolnya. Berbagai sisi kehidupan dijadikan tema penerbitan, mulai dari anak-anak, wanita, kriminal, politik, ekonomi, agama, remaja, dan sebagainya, menjadi tema penerbitan dan penyiaran. Masyarakat mempunyai banyak alternatif untuk memilih jenis media yang dianggap sesuai. Kebebasan dalam pemberitaan atau 
pengungkapan suatu peristiwa lebih gamblang dan transparan selama era reformasi, kondisi ini sejalan dengan konsep "masyarakat madani” yang beberapa tahun terakhir dipopulerkan oleh cendekiawan Muslim Nurcholish Madjid (alm).

Konsep pemikiran masyarakat madani berasal dari pemikiran Nabi Muhammad saw, yang memberi teladan kepada manusia ke arah pembentukan masyarakat berperadaban. Muhammad meletakkan dasar-dasar masyarakat madani, dengan bersama semua unsur penduduk Madinah, menggariskan ketentuan hidup bersama dalam suatu dokumen yang dikenal sebagai "Piagam Madinah" (mitsaq al-Madinah). Dalam dokumen inilah, untuk pertama kalinya manusia diperkenalkan tentang wawasan kebebasan, terutama di bidang agama dan ekonomi, tanggung jawab sosial, dan politik, khususnya pertahanan bersama. Atas pertimbangan ajaran itulah Nabi dalam rangka menegakkan masyarakat madani atau civil society tidak pernah membedakan antara "orang atas", "orang bawah" ataupun keluarga sendiri. Beliau pernah menegaskan bahwa hancurnya bangsabangsa di masa dahulu adalah karena jika "orang atas" melakukan kejahatan dibiarkan, tapi jika "orang bawah" melakukannya pasti di hukum.

Pemberitaan di media massa dalam konsep kehidupan masyarakat madani tidak terlepas dari pemikiran nabi tersebut. Setiap orang layak menjadi subjek pemberitaan apabila memang memenuhi kepentingan umum dan setiap orang juga berhak untuk memilih dan mendapatkan berita yang diinginkannya. Kebebasan media massa dalam kehidupan masyarakat madani sebenarnya bukanlah kebebasan yang mutlak, karena proses sensor masih tetap dilakukan, antara lain melalui norma, etika, kebudayaan, agama, dan adat istiadat yang berlaku di masyarakat. Dengan kata lain, media massa bukanlah sesuatu yang bebas, independen, tetapi memiliki keterkaitan dengan realitas sosial.

Sementara itu, Antonio Gramsci (dalam Sobur, 2001:30) melihat media sebagai ruang di mana berbagai ideologi direpresentasikan. Ini berarti, di satu sisi media bisa menjadi sarana penyebaran ideologi penguasa, alat legitimasi, dan kontrol atas wacana publik; namun di sisi lain, media massa juga bisa menjadi alat resistensi terhadap kekuasaan.

Media massa di tanah air di kenal sebagai pers Pancasila di mana kebebasan yang dilakukan juga disertai dengan tanggung jawab sosial, penyebaran informasi harus dalam batas objektivitas, melaksanakan kontrol sosial (semua pihak dan keadaan) secara konstruktif, dan meningkatkan partisipasi masyarakat terhadap pembangunan. Dalam menggunakan kondisi kebebasan pers, seorang wartawan yang baik wajib menghayati pertanggungjawabannya terhadap hati nurani sendiri, sesama warga negara, kepentingan umum yang diwakili oleh pemerintah dan sesama rekan seprofesi.

Membandingkan antara sistem pers Indonesia atas empat sistim pers dunia lainnya (authoritarian theory/teori otoriter, libertarian theory/ teori liberal, social responsibility theory/teori pertanggungjawaban sosial, dan soviet communist theory/teori komunis), maka ada kemiripan antara sistem pers Indonesia dan sistem pertanggungjawaban sosial. Ketetapan MPR-RI Nomor II/MPR/1983 tentang GBHN di dalamnya, antara lain, menyebutkan fungsi pers Indonesia sebagai berikut :

(1) Penyebar informasi yang objektif

(2) Melakukan kontrol sosial yang konsumtif

(3) Menyalurkan aspirasi rakyat

(4) Meningkatkan komunikasi dan partisipasi masyarakat.

Ke empat fungsi pers atau media massa di atas masih berlaku dalam kondisi masyarakat madani. Media massa menjadi sarana bagi penyampaian keingintahuan masyarakat mengenai segala hal mengenai dirinya dan berbagai kejadian yang terdapat di sekitarnya.

\section{Pembahasan}

Media massa modern menunjukkan sistem di mana pesan-pesan diproduksi, dipilih, disiarkan, diterima, dan ditanggapi oleh komunikan. Komunikasi massa menyiarkan informasi, gagasan, dan sikap kepada komunikan yang beragam dalam 
jumlah yang banyak dan menggunakan media. Media massa mempunyai karakteristik massal, yang termasuk di dalamnya adalah pers (media cetak), radio, televisi, dan film. Keempat jenis media massa ini berpengaruh terhadap tatanan kehidupan masyarakat madani dan pembangunan.

Peran media massa dalam pembangunan menuju masyarakat madani, menurut Gunadi (1998:88) adalah sebagai berikut :

(1) Menjaga kepentingan umum, informasi yang disampaikan media massa membuat masyarakat sadar akan kepentingan mereka, dalam arti tidak terganggu, malah menguntungkan dengan adanya pembangunan.

(2) Membentuk opini, kesadaran ini menggugah pemikiran dan pembahasan serta dialog yang akhirnya membawa kepada satu kesamaan pendapat.

(3) Mendidik, semakin luas dan semakin banyak pembangunan akan mendorong masyarakat untuk semakin giat mencari pengetahuan baru.

Lebih jauh, mengenai manfaat dari peranan media massa dalam pembangunan menuju masyarakat yang madani, yaitu sebagai berikut :

(1) Memperluas pandangan, peranan ini membuat media massa seumpama sebuah puncak bukit, dalam hal ini masyarakat penerima informasi itu sendiri. Mereka bisa melihat ke sekelilingnya dengan lebih luas, melewati batas-batas yang menghalangi pandangan. Kondisi begitu terasa pada media massa dalam masyarakat madani, di mana telah terjadi globalisasi media massa dan tanpa batas. Perkembangan media massa dengan kecanggihan teknologi komunikasi yang dipergunakan, membuat ruang, waktu, dan jarak menjadi singkat. Penikmat media massa bisa melihat, merasakan, menikmati, dan mengetahui berbagai kejadian yang terjadi di belahan dunia lain. Dunia tanpa batas yang hadir melalui media massa berdampak kepada perubahan cara pandang masyarakat, bisa ke arah yang lebih baik tetapi juga bisa ke arah yang buruk.
(2) Meningkatkan pengharapan, harapan yang akan berhasil ditingkatkan oleh media massa, bukan saja berupa harapan masing-masing individu tetapi juga aspirasi nasional secara keseluruhan. Lihatlah bagaimana media massa dalam proses Pemilu 2004 telah menumbuhkan harapan-harapan bagi individu maupun golongan tertentu. Melalui media massa, bisa di lihat bagaimana pengharapan publik terhadap perkembangan situasi Pemilu dan loyalitas terhadap partai politik, harapan kandidat wakil rakyat, sampai pada kandidat presiden dan wakil presiden,

(3) Menggairahkan iklim pembangunan, pengharapan yang berhasil ditimbulkan akan memudahkan masyarakat untuk diajak serta (partisipasi) dalam mengisi, dan meningkatkan pembangunan.

(4) Menjaga kepentingan umum, sejauh ini kehadiran media massa memang ditujukan untuk kepentingan umum, media massa akan menunjukkan kepada masyarakat apa yang baik atau tidak baik untuk kepentingan masyarakat.

(5) Mengubah sikap lama, peranan ini bisa dilakukan media massa secara tidak langsung atau tahap demi tahap agar sesuai dengan sikap lama yang tidak sesuai dengan iklim dan tujuan pembangunan yang sedang dilaksanakan. Perubahan terhadap cara pandang atau sikap lama yang dilakukan media massa ini bertujuan agar pembangunan yang sedang dilaksanakan tetap selaras dengan perkembangan kehidupan masyarakat.

(6) Penyalur umpan balik, kebijakan pembangunan dari pemerintah bukan saja bisa diterima masyarakat lewat media massa, melainkan juga melalui media massa masyarakat bisa diajak membahas dan bersuara demi peningkatan partisipasi, artinya feedback dari masyarakat dapat disalurkan melalui media massa. Dalam kehidupan masyarakat madani, feed back dari masyarakat sangat dibutuhkan dalam mengontrol arus pembangunan yang dilaksanakan. Media 
massa merupakan tempat yang tepat bagi penyaluran feed back tersebut karena bisa menyentuh berbagai kalangan, terutama pemerintah.

(7) Membina keinginan bersama, peranan ini penting untuk manusia Indonesia yang terdiri atas berbagai daerah, suku bangsa serta pandangan hidup yang berbeda-beda. Maksudnya, agar tercipta perasaan sama dan rasa kerukunan guna mencapai cita-cita pembangunan.

(8) Mendidik, media massa dalam kondisi ini bisa secara langsung dan bisa juga tidak langsung dengan menggugah masyarakat untuk belajar lebih banyak lagi. Pesan-pesan pendidikan yang dikomunikasikan melalui media massa di kemas ke dalam berbagai bentuk pemberitaan (penayangan), mulai dari yang sifatnya serius (terfokus kepada pendidikan) maupun yang lebih santai (penggabungan antara unsur pendidikan dengan hiburan/edutainment).

(9) Pemberi bahan untuk pemimpin pembangunan, dalam sistem komunikasi sosial yang memanfaatkan sistem interpersonal communication, pemimpin masyarakat memerlukan bahan-bahan untuk disampaikan kepada masyarakat, agar pengarahan pimpinannnya lebih mantap diterima masyarakat.

(10) Membina kewibawaan pimpinan, pemberitaan tentang apa, siapa, dan bagaimana tokoh pimpinan yang baik, akan meninggikan nama dan memperkuat kewibawaan pimpinan tersebut di mata masyarakat.

Berdasarkan beberapa peranan dan manfaat media massa dalam pembangunan menuju masyarakat madani di atas, maka secara sederhana ada empat asumsi kondisi media massa dalam kehidupan masyarakat madani, yaitu adanya keterbukaan dalam proses penyebaran informasi melalui media massa, terciptanya sebuah agenda dalam proses penyebaran berita dan informasi, adanya hubungan yang baik antara sesama media massa, pemerintah, dan masyarakat, serta tidak menyimpulkan sesuatu hal. Ke empat asumsi tersebut dijelaskan sebagai berikut:
(1) Keterbukaan dalam proses penyebaran informasi melalui media massa.

Nurcholish Madjid (1998:176) mengatakan bahwa masyarakat madani bakal terwujud hanya jika terdapat cukup semangat keterbukaan dalam masyarakat. Artinya, ada kerendahan hati untuk tidak merasa selalu benar, kesediaan mendengar pendapat orang lain, mengikuti dan mengambil nilai-nilai terbaik. Keterbukaan adalah konsekuensi dari perikemanusiaan, suatu pandangan yang melihat sesama manusia secara positif dan optimis, yaitu pandangan bahwa manusia pada dasarnya adalah baik, sebelum terbukti sebaliknya. Berdasarkan konsep sederhana ini, keterbukaan media massa hendaknya bisa dirasakan oleh semua lapisan masyarakat, masyarakat berhak tahu apa yang terjadi, berdasarkan fakta dan bukan merupakan manipulasi fakta dan data.

Hingga saat ini keterbukaan pada kehidupan media massa terutama terlihat pada tingkat fenomena sosial. Berbagai kejadian, masalah yang terjadi baik di "kalangan atas" maupun "kalangan bawah" di angkat ke permukaan, layak diketahui dan menjadi konsumsi masyarakat luas, masyarakat menggunakan haknya untuk "tahu" atau the right to know. Setiap media massa berpacu memenuhi kebutuhan khalayak, mencari berbagai agenda menarik agar selalu mendapat prioritas bagi masyarakat.

Dalam keterbukaan pada tingkat fenomena sosial masyarakat, kebutuhan akan media massa bukan hanya sebatas kerinduan pada berita-berita mengenai kejadian umum tetapi juga kerinduan akan interpretasi dan evaluasi dari kejadiankejadian tersebut. Begitu pula para ahli jurnalistik modern telah mengubah penonjolan pelaporan fakta murni menjadi fakta yang disertai dengan interpretasi, tentunya tanpa mengurangi nilai berita yang disajikan . Idiom man make news dan news make man dalam proses pengolahan suatu berita untuk media massa, membuat banyak ahli jurnalistik sekarang memperluas batas pekerjaan mereka untuk memasukkan tanggung jawab mengevaluasi dan menginterpretasikan kejadian-kejadian di dalam konteks sosial dan historikal yang lebih luas 
serta mengevaluasi berbagai macam sumber dari mana fakta itu muncul. Namun, sebagian pihak menganggap bahwa keterbukaan yang diterapkan oleh media massa saat ini sebagai wujud dari kebebasan bermedia yang kebablasan, yang memunculkan istilah euforia-pesta kebebasan yang kelewatan hingga dinilai bisa mereduksi tanggung jawabnya. Mursito (2000:20) menganggap bahwa media massa dalam masyarakat madani dipenuhi oleh pendapat yang beragam, dalam menanggapi isu yang ditampilkan, pendapat-pendapat tersebut ada yang berkualitas baik dalam arti didukung oleh fakta dan argument, dinyatakan dalam format yang sistimatis dan terstruktur, tetapi banyak pula yang asal.

(2) Terciptanya sebuah agenda dalam proses penyebaran berita dan informasi.

Jika kita perhatikan apa yang terjadi dalam kenyataan hidup sehari-hari, jelas sekali bahwa nilai-nilai kemasyarakatan yang terbaik, sebagian besar dapat terwujud hanya dalam tatanan hidup kolektif yang memberi peluang pada adanya pengawasan sosial. Tegaknya hukum dan keadilan mutlak memerlukan suatu bentuk interaksi sosial yang memberi peluang bagi adanya pengawasan tersebut. Pengawasan sosial yang dilakukan masyarakat terhadap media massa, antara lain, adalah dengan mengikuti perkembangan demi perkembangan atas suatu kasus yang menjadi agenda di media massa. Hal ini menyebabkan terjadinya pengulasan atas satu kasus secara menyeluruh, mendalam dan mendekati tuntas (karena masih ada beberapa kasus yang hadir, menjadi agenda di media massa kemudian hilang begitu saja).

Dalam teori komunikasi massa, pengagendaan ini dikenal dengan agenda setting theory yang diteliti oleh Mc Combs dan Shaw (1972). Teori ini dimulai dengan suatu asumsi bahwa media massa menyaring berita, artikel, atau tulisan yang akan disiarkannya (Rakhmat, 1988:260). Inti dari teori ini adalah apa yang menjadi agenda bagi media massa akan menjadi agenda juga pada masyarakat, karena pembaca, pemirsa, dan pendengar memperoleh kebanyakan informasi melalui media massa. Setiap kejadian atau isu dalam teori ini, diberi bobot tertentu dengan panjang penyajian (ruang dalam surat kabar, waktu pada televisi dan radio) dan cara penonjolan (ukuran judul, lay out, frekuensi pemuatan, durasi siaran, dan sebagainya). Agenda setting memengaruhi kondisi media massa di tanah air, mencuatkan nama-nama tempat atau orang setelah media massa secara berkala memberitakannya.

Dalam kondisi masyarakat madani saat ini, isu sentral dari pemberitaan di media massa yang menghangat adalah mengenai masalah politik, apalagi menjelang pemilihan presiden dan wakil presiden. Selama setahun terakhir, isu politik menghiasi semua media massa, menyediakan ruang dan tempat dalam porsi yang lebih banyak dari biasanya, apalagi menjelang pemilu 5 Juli 2004. Setiap media massa seolah berpacu meciptakan bentuk agenda yang menarik dan menyedot perhatian masyarakat. Program acara talk show di televisi, misalnya, merupakan salah satu bentuk agenda media massa yang tanpa sadar sudah menjadi agenda pula di masyarakat. Keterbukaan untuk membahas setiap kasus melalui berbagai nara sumber, menggiring khalayak yang menyaksikan pada pembentukan opini publik (bisa negatif, bisa poisitif).

Media massa dalam kondisi di atas, menurut Jalaluddin Rakhmat, terbukti sanggup berperan membentuk citra orang tentang lingkungan dengan menyampaikan informasi, dan berperan juga dalam menyampaikan pengetahuan, keterampilan, dan nilai-nilai yang baik. Suatu kasus atau fokus pemberitaan yang menjadi agenda di media massa, akhirnya menuju kepada arah penyelsaian konflik. Masyarakat diajak untuk mengulas hingga tuntas, memberikan feed back, tanggapan serta responsive mereka terhadap media, apakah melalui suara pembaca maupun surat pembaca.

(3) Adanya hubungan yang baik antara sesama media massa, pemerintah, dan masyarakat.

Komunikasi juga ditujukan untuk menumbuhkan hubungan sosial yang baik, karena secara kodrati manusia adalah makhluk sosial yang tidak bisa hidup sendiri. Manusia membentuk hubungan satu sama lain, berkomunikasi dengan 
manusia lainnya, sehingga terciptalah sebuah jaringan sosial yang akhirnya membentuk sebuah masyarakat. Dalam tatanan kehidupan masyarakat madani, media massa mempunyai hubungan yang baik dengan semua unsur, meskipun hingga saat ini, masih ada kepemilikan kelompok tertentu atas suatu media massa untuk menyuarakan kepentingan kelompoknya.

Dofivat (dalam Rakhmat, 1988:212) mengingatkan kita tentang kemungkinan dikontrolnya media massa oleh segelintir orang untuk kepentingan sendiri, sehingga jutaan manusia kehilangan kebebasannya. Dengan kata lain, kontrol media massa oleh kelompok tertentu masih akan terus terjadi, karena betapapun juga pers dalam perkembangan sekarang ini sudah menjadi bagian dari industri. Alex Sobur menjelaskan kondisi ini yaitu bahwa media bisa menjadi alat untuk membangun kultur dan ideologi dominan bagi kepentingan kelas dominan, sekaligus juga bisa menjadi instrumen perjuangan bagi kaum tertindas untuk membangun kultur dan ideologi tandingan (Sobur, 2001:30).

Terlepas dari dominasi kepentingan kelompok tertentu terhadap suatu jenis media massa, dalam prakteknya, hubungan antarmedia massa saat ini merupakan satu harmonisasi untuk memenuhi fungsinya sebagai sarana informasi, pendidikan, hiburan dan pengaruh. Dalam pemberitaannya, baik media massa cetak maupun elektronik saling mengisi bekerja sama dan bahkan mengolah data, fakta, dan informasi bersama. Tak jarang pula hubungan baik yang terbentuk antarsesama media massa ini menimbulkan kebosanan bagi publik, karena apa yang di informasikan tersebut sering seragam antara satu media dengan media lainnya. Hal ini sangat terlihat dari maraknya tayangan acara infotainment (pada umumnya berupa gossip tentang public figure/selebritis). Masyarakat direcoki oleh beragam aktivitas para public figure, mulai dari masalah ringan sampai masalah berat tentang kehidupan mereka.

Kebersamaan yang ditampilkan oleh media massa dalam hal ini misalnya dalam proses peliputan berita, karena tak jarang satu peristiwa diliput secara bersamaan, di tayangkan secara bersamaan oleh media massa. Hubungan baik yang terbentuk oleh media massa ini juga terjadi antara pemerintah dan masyarakat. Bila pada masa Orde Baru kedudukan pers dan masyarakat berada di bawah kontrol pemerintah secara ketat, maka pada masyarakat madani saat ini posisi masing-masing komponen sistem mengalami pergeseran, di mana pemerintah bukan lagi merupakan pusat pengontrolan bagi semua kegiatan pers.

\section{(4) Tidak membuat kesimpulan.}

Sebagai kekuatan keempat (the fourth estate) setelah lembaga legislatif, eksekutif, dan yudikatif, media massa pantas mendapat julukan sebagai watch dog (anjing penjaga), yang mengawasi berbagai kejadian atau peristiwa yang terjadi di sekitarnya. Media massa dalam kondisi ini, menurut Sobur (2001:31), merupakan suatu alat untuk menyampaikan berita, penilaian, atau gambaran umum tentang banyak hal, ia mempunyai kemampuan untuk berperan sebagai institusi yang dapat membentuk opini publik, antara lain, karena media juga dapat berkembang menjadi kelompok penekan atas suatu ide atau gagasan, dan bahkan suatu kepentingan atau citra yang ia representasikan untuk diletakkan dalam konteks kehidupan yang lebih nyata. Sejalan dengan keterbukaan yang sudah disinggung sebelumnya, masyarakatlah yang mempunyai peranan menentukan bagaimana bentuk citra yang direpresentasikan oleh media massa.

Media massa tidak menunggu peristiwa lalu mengejar, memahami kebenarannya, dan memberitakannya kepada publik. Ia mendahului semua itu, ia menciptakan peristiwa. Menafsirkan dan mengarahkan terbentuknya kebenaran. Dengan demikian, keberadaan media massa saat ini bukanlah merupakan kartu mati. Artinya, media bukan merupakan juri yang siap memberikan vonisnya terhadap suatu peristiwa yang sedang menjadi pusat perhatian masyarakat. Sesuai dengan konsep masyarakat madani, maka media massa hanya merupakan sarana bagi pembentukan opini publik yang seimbang, tidak berpihak dan tidak menghakimi. Media massa hanya menjalankan fungsinya sebagai agen informasi, menyampaikan kepada masyarakat fakta dan data yang terdapat di 
lapangan, dan menyerahkan penilaianya kepada masyarakat.

\section{Kesimpulan}

Keterbukaan, kebebasan, dan tanggung jawab media massa pada masyarakat madani tidak berada pada koridor yang tetap. Masyarakat dituntut untuk menjadi massa yang aktif, mempunyai filter dan daya tahan yang kuat terhadap pesan yang dibawa oleh media massa.

Media massa dalam masyarakat madani dipandang sebagai salah satu komponen penting dalam struktur sosial. Pada posisinya, media massa mempunyai fungsi untuk memelihara stabilitas dan harmoni antara komponen yang lain dalam masyarakat dengan menyampaikan informasi yang terbuka, ke arah penyelesaian konflik melalui sistem pengagendaan yang terus menerus, serta tidak menciptakan sebuah kesimpulan. Media massa juga merupakan sebuah institusi sosial yang berada di antara institusi budaya, politik, ekonomi dalam masyarakat. Semoga dengan terjadinya pergeseran paradigma dalam kehidupan media massa saat ini, bisa mendukung stabilitas kehidupan masyarakat madani ke arah yang lebih baik, stabil, dan menunjang pembangunan nasional.

\section{Daftar Pustaka}

Effendy, O, Uchjana. 1984. Televisi Siaran Teori dan Praktek. Bandung: Alumni.

. 1993. Ilmu Teori dan Filsafat Komunikasi. Bandung: Citra Aditya Bakti.

Fakih, Mansour. 1996. Masyarakat Sipil. Yogyakarta: Pustaka Pelajar.

Gunaldi, YS. 1998. Himpunan Istilah Komunikasi. Jakarta: Grasindo.

Jurnal ISKI. 2000. Industri Pers dan Prospek Kebebasannya. Bandung: Remaja Rosdakarya.

Madjid, Nurcholish. 1998. Cita-cita Politik Islam Era Reformasi. Jakarta: Paramadina.

Mulyana, Deddy. Nuansa-Nuansa Komunikasi. Bandung: Remaja Rosdakarya.

Rakhmat, Jalaluddin. 1988. Psikologi Komunikasi. Bandung: Remaja Rosdakarya.

Sobur, Alex. 2001. Analisis Teks Media. Bandung: Remaja Rosdakarya.

Wright, Charles R. 1986. Sosiologi Komunikasi. Bandung: Remaja Rosdakarya. 
